Academic Platform Journal of Engineering and Science

journal homepage: http://apjes.com/

\title{
Numerical Study on Suspended Sediment Transport under the Effect of Water Temperature in Reservoirs and Lakes
}

\author{
*1Redvan Ghasemlounia, ${ }^{2}$ Mehmet Sedat Kabdaşlı \\ ${ }^{* 1}$ Dept of Civil Eng., Faculty of Engineering, Istanbul Gedik University, Turkey, redvan.ghasemlounia @ gedik.edu.tr, \\ ${ }^{2}$ Faculty of Civil Engineering, Istanbul Technical University, Turkey, kabdaslis@itu.edu.tr, (D)
}

Research Paper

Arrival Date: 17.08 .2020

Accepted Date: 15.04.2021

\begin{abstract}
Water resources management is one of the most important issues and challenges in the world. This management may be in the form of quality management or quantitative management of water resources. Quality management of water resources is of great importance. A major problem in this case is how the input flow (for example a river) will behave when water flows to a dam reservoir or lake. Distribution of the input stream to the reservoir/lake depends on important parameters such as inflow discharge, input depth, situation and type of the reservoir outlet, type of inlet sediment, sediment concentration of inflow current and reservoir/lake, and etc. Therefore, this effect of each of the mentioned parameters on the distribution in the reservoir or lake should be examined. An important parameter that has not yet been studied is the effect of temperature of the inflow current's and the reservoir/lake's water on the distribution. For this purpose, the FLOW3D computational fluid dynamics code was selected in this study. The effect of water temperature and concentration of suspended sediment on distribution in reservoirs/lakes is considered. Several simulations with different water temperature and suspended sediment concentration values were done. Results are shown and compared each other. The results indicate the high effect of water temperature on distribution of sediments. The rising in water temperature value leads to settling the suspended sediments faster. Therefore, the temperatures of inflow and reservoir water affect the depositing and settling of suspended sediments.
\end{abstract}

Keywords: Reservoirs and lakes, Sediment transport, FLOW3D, Suspended sediment, Water Temperature

\section{INTRODUCTION}

Nowadays, aridness is the main problem for the arid and semi-arid regions. On this basis, the preservation of the water resources has high attention and particular importance. For this reason, policies and patterns of water use have major role. One of these policies is construction of dams. The importance of dam construction in these regions has increased in recent years. Therefore, in these regions, dams are important manmade structures, because they are the only source of water during water shortage seasons. In arid and semi-arid countries, dams are mostly constructed for supplying the drinking water and irrigation. Here, management of these resources plays a major role than the construction of them. So, water resources need a good management in the present century because of these limitations of water resources, especially. For better management of water resources, investigation of all parameters of the hydrologic cycle and climatic characteristics including precipitation, wind, temperature, runoff, evaporation and etc. is required. These natural and climatic characteristics affect the water quality of the water resources, dam reservoirs and lakes. In this study, dam reservoirs and lakes are considered. There are several factors and phenomena that affect the quality of water in lakes and reservoirs. One of the most important problems that occur in dam reservoirs is sedimentation. There are some problems caused by sedimentation in dam reservoirs such as decreasing of storage volume of the reservoirs after operation. Sedimentation is the main phenomena that lead to dam death. This phenomenon is endangering the life of dams, insensibly and during the time, gradually. Beyond that sedimentation makes project uneconomical; in arid and semi-arid regions, it is important especially due to water shortage. Evaluation of sedimentation and the distribution of sediments in dam reservoir is necessary to increase the efficiency of hydro facilities. One of the other phenomena that affect water quality in reservoirs is named as stratification [1].This phenomenon is a result of the available differences between the input river and lake water's density in terms of temperatures and suspended sediments. In addition to research on stratification and its impacts on water quality, it is important to examine how these layers are formed. Study of stratification phenomena has special significance because of the importance of water quality. Stratification in lakes and dam reservoirs has two forms as: thermal stratification and the stratification that caused by concentration of suspended particles. Each of these phenomena could affect the water quality of reservoirs or lakes, extremely. So, study on these 
phenomena is one of the important subjects that should be done in water resources management in reservoirs and lakes, especially. Stratification has important implications for fisheries management, phytoplankton (algae) populations, and water supply quality, generally. Currents have different distribution behavior, when reach to the reservoir/lake based on their density, which is extremely influenced by their water temperature, discharge and suspended sediment concentration. Types of flows according to differences between density of river flow and density of water in reservoir or lake are defined here. When a river flow with the density equal to $\rho_{\text {river }}$ comes into the reservoir or lake with density of $\rho_{\text {reservoir/lake, it can has one }}$ of the following behaviors shown in Figure 1, totally [2, 3].

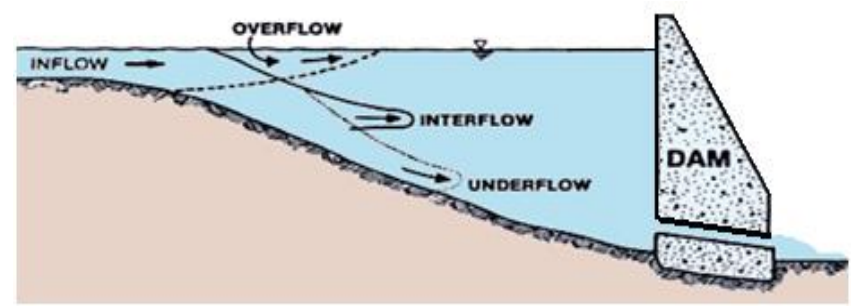

Figure 1. Behavior of river water meets reservoir/lake [3].

Over flow, inter flow and under flow also could be named as Hyperpycnal, Hypopycnal, Homopycnal and Hyperpycnal flow, respectively. Numerous studies are available in the case of sediments motion and sediment distribution in reservoirs and lakes due to changes in conditions of inflowing river and reservoir/lake. Several experimental and numerical studies related to the sediment transport are done by many researcher and scientists. But there isn't any study about the effect of the water temperature on distribution and transport of the suspended sediment particles. For example, Milliman (1981) studied on the transfer of river-born particular material to the ocean river inputs to ocean systems [4]. Van Rijn (1984) studied on the suspended sediment transport, and investigated the parameters controlling the suspended load transport [5]. In another research, Williams (1989) studied on the topic titled as sediment concentration versus water discharge during single hydrological events in rivers and investigated the relation between sediment concentration and water discharge [6]. Kostic and Parker (2003) have developed a moving boundary model of deltaic sedimentation in lakes and reservoirs [7]. Salant et al. (2008) concluded the directly relation between suspended sediment concentrations and discharge [8]. Algan et al. (2000) investigated the sediment and freshwater discharges of the Anatolian river into the Black sea [9]. Fang \& Wang (2000) worked on a topic entitled three-dimensional mathematical model of suspended-sediment transport [10]. They predicted the deposition of suspended sediment in Yangtze River. United States Sociecty of Dams, Committee on Hydraulics of Dams, Subcommittee on Reservoir Sedimentation (USSD) studied and prepared a report under titled the modeling sediment movement in reservoirs (2015) [11].
Many other researchers found the significance of the effects of thermal stratification on the hydrodynamic mixing, contaminant transport, and water quality of reservoirs and lakes [13, 14, 15, 16, 17]. Dake and Harleman (1969) investigated the analytical and laboratory studies of thermal stratification in lakes [12]. Modiri-Ghareveran et al. (2013) worked on effects of climate change on the thermal regime of a reservoir. They modeled the thermal stratification of Latian dam [18]. Baharim et al. (2011) investigated the effects of thermal stratification on the concentration of iron and manganese in a tropical water supply reservoir [19]. Nazariha et al. $(2009,2010)$ predicted the thermal stratification in proposed Bakhtiyari reservoir [20]. Nsiri et al. (2016) modeled the thermal stratification and the effect on water quality in four reservoirs in Tunisia [21]. Cossu et al. (2015) investigated the subject under the title of seasonal variability in turbidity currents in Lake Ohau and their influence on sedimentation [22]. Akiyama and Stefan (1984) summarized equations proposed by several investigators for determining the plunge depth [23]. Farrell and Stefan (1986) reported about buoyancy induced plunging flow into reservoirs and coastal regions in a project of Minnesota and studied on mathematical modeling of plunging reservoir flows [24].

Some other researchers studied on effect of water temperature on stratification and sediment transport. the most recent study related this subject is done by Zhong et al. (2020). They worked on impact of cold water mass on suspended sediment transport in the South Yellow Sea [26]. Other recent study was the role of saltwater and waves in continental shelf formation with seaward migrating clinoform, which was done by Iwasaki and Parker in 2020 [27].

Evaluating these literatures and many other studies, it is concluded that there isn't any study about the effect of the water temperature on distribution and transport of the suspended sediment particles. The main use of results of this study is to improve the dam reservoirs or lakes operation. Because it is necessary to predict effects of sediment distribution and loss of storage capacity and its rate for better operation of the reservoirs.

\section{MATERIAL AND METHOD}

Eight scenarios were simulated according to table 2, which will described in section 2.2. Based on these selected scenarios, the temperature range between $4-40{ }^{\circ} \mathrm{C}$. Where, the suspended sediment concentrations were 15 and 20 $\mathrm{kg} / \mathrm{m}^{3}$ depending on the selcted simulation. The computational code, which was choosen for this work, the governing equation used by this code and the information about numerical model are explained in sections 2.1 and 2.2.

\subsection{Governing Equations}

A three-dimensional numerical modeling was used in the present study to model the hydrodynamics in reservoirs or lakes. FLOW-3D computational fluid dynamic code was 
selected for numerical solutions because of its capabilities and advantages. Continuity, momentum and energy equations are presented as Equation (1), (2) and (3), respectively [25].

$\frac{\partial \rho}{\partial t}+\frac{\partial}{\partial x}(\rho u)+\frac{\partial}{\partial y}(\rho v)+\frac{\partial}{\partial z}(\rho w)=0$

$\frac{\partial \mathrm{u}}{\partial \mathrm{t}}+\mathrm{u} \cdot \nabla \mathrm{u}=\mathrm{f}-\frac{1}{\rho} \nabla \mathrm{P}+\mathrm{u} \nabla^{2} \mathrm{u}$

$\frac{\partial \bar{T}}{\partial t}+\bar{u} \frac{\partial \bar{T}}{\partial x}+\bar{v} \frac{\partial \bar{T}}{\partial y}+\bar{w} \frac{\partial \bar{T}}{\partial z}+f \bar{u}=\alpha_{e f f}\left(\frac{\partial^{2} \bar{T}}{\partial x^{2}}+\frac{\partial^{2} \bar{T}}{\partial y^{2}}+\frac{\partial^{2} \bar{T}}{\partial z^{2}}\right)$

Suspended Sediment Transport Equation is an important equation that must be noticed in the case of sediment motion this equation is shown as Equation (4) [25].

$\frac{\partial c}{\partial t}+u_{i} \frac{\partial c}{\partial x_{i}}=\frac{\partial}{\partial x_{i}}\left(\Gamma \frac{\partial c}{\partial x_{i}}-\overline{u_{i}^{\prime} c^{\prime}}\right)+S_{c}$

In this equation, $\mathrm{c}$ is the suspended sediment concentration $(\mathrm{mg} / \mathrm{l}), \Gamma$ is the molecular diffusivity coefficient, $\mathrm{S}_{\mathrm{c}}$ is the sink or source of $\mathrm{c}$. The term $-\overline{\mathrm{u}_{\mathrm{i}}^{\prime} \mathrm{c}^{\prime}}$ is called the turbulent diffusion of $\mathrm{c}$.

\subsection{Numerical Model}

A reservoir (Figure 2) was designed and defined to FLOW3D, which has an entrance and an outlet. The geometry of reservoir is created using its own modeler (using the Flow 3D GUI and solids modeler). For drawing the geometries, components should be created first. Each model, which created in this study, has a component and 3 subcomponents. FLOW 3D creates subcomponents as solid objects by default, and this is the only option when the subcomponent belongs to a new component. Geometry of the reservoir has about 390 meters length, 120 meters width and 60 meters depth, when reservoir capacity is completely full.

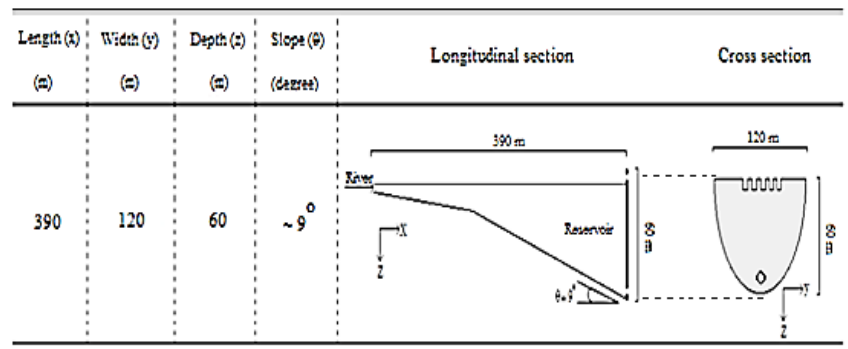

Figure 2. The selected dimensions for the models.

Mesh structure of models using for this study consists of four mesh blocks in all simulations. These blocks are Block1, Block2, Block 3 and Block 4, which are represented in Figure 3.

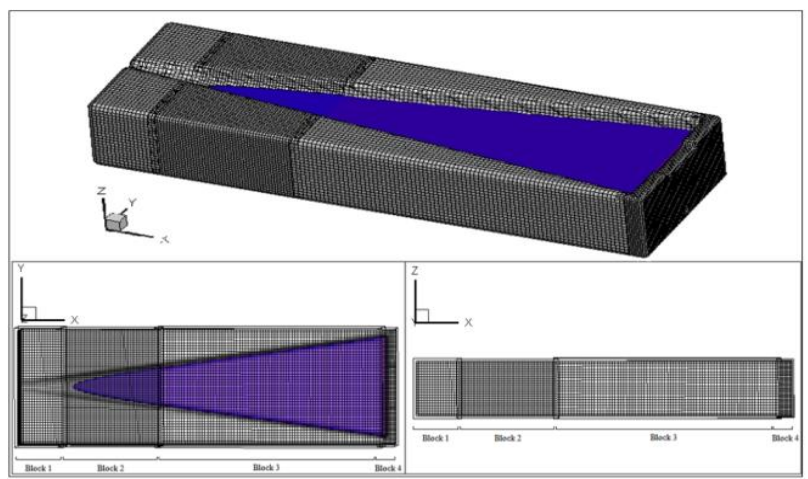

Figure 3. Mesh structure of models.

Blocks and grids information of the models are presented in Table 1. The cells in Block 2 and 4 are smaller than the other block. In Block 2, condition is similar to shallow water condition. So, the details are very important in this region. On the other hand, in block 4, a spillway is available. Then, the smaller cells are needed to creation of a good shaped structure of these outlets.

Table 1. Mesh and Grid Information of Geometry

\begin{tabular}{|c|c|c|c|c|c|c|}
\hline $\begin{array}{c}\text { Mesh } \\
\text { Block No. }\end{array}$ & Direction & $\begin{array}{l}\text { Total number of } \\
\text { real cells }\end{array}$ & $\begin{array}{l}\text { Min. cell } \\
\text { size }\end{array}$ & $\begin{array}{l}\text { Max. } \\
\text { cell size }\end{array}$ & $\begin{array}{l}\text { Total number of } \\
\text { real cells of } \\
\text { each block }\end{array}$ & $\begin{array}{l}\text { Total number } \\
\text { of real cells in } \\
\text { model }\end{array}$ \\
\hline \multirow{3}{*}{ I } & $\mathrm{x}$ & 18 & 2.50 & 2.50 & \multirow{3}{*}{17802} & \multirow{12}{*}{201314} \\
\hline & y & 43 & 2.50 & 2.50 & & \\
\hline & $z$ & 23 & 2.52 & 2.52 & & \\
\hline \multirow{3}{*}{ II } & $\mathrm{x}$ & 48 & 1.87 & 1.87 & \multirow{3}{*}{87552} & \\
\hline & $y$ & 57 & 1.86 & 1.86 & & \\
\hline & z & 32 & 1.89 & 1.89 & & \\
\hline \multirow{3}{*}{ III } & $\mathrm{x}$ & 78 & 2.69 & 2.69 & \multirow{3}{*}{67080} & \\
\hline & $\mathrm{y}$ & 43 & 2.68 & 2.68 & & \\
\hline & z & 20 & 2.65 & 2.65 & & \\
\hline \multirow{3}{*}{ IV } & $\mathrm{x}$ & 10 & 1.44 & 1.44 & \multirow{3}{*}{28880} & \\
\hline & $\mathrm{y}$ & 76 & 1.44 & 1.44 & & \\
\hline & $z$ & 38 & 1.43 & 1.43 & & \\
\hline
\end{tabular}

$\mathrm{X}_{\min }$ was selected as the inflow boundary. The defined boundary condition for this point of model was volume flow rate, which defines the inflow discharges to the e FLOW-3D $\left(\mathrm{V}_{\text {fr }}\right.$ or $\left.\mathrm{Q}\right)$. For this boundary condition, inflow 
discharge, sediment concentration of inflow water and the thermal information of inflow water were adjusted, depends on the selected models. Here, the values and parameters were set as time-dependent conditions. The boundary condition at $\mathrm{x}_{\max }$, in block number 4 in models, was selected as outflow boundary $(\mathrm{O})$, where the body of the dam is located. The outflows were considered as a spillway at the dam crest and the lower outlet near the bottom of the body of dam. In this study, only $S$ models were investigated, which represents models that only spillway operated. The bottom $\left(\mathrm{z}_{\min }\right)$, right $\left(\mathrm{y}_{\min }\right)$ and left $\left(\mathrm{y}_{\max }\right)$ boundary conditions of reservoir were selected as wall type (W). In this type of boundaries, fluid could not be entered to the boundary. Zmax boundary of models was defined as the symmetry condition (S). Figure 4 represents these boundary conditions (BCs).

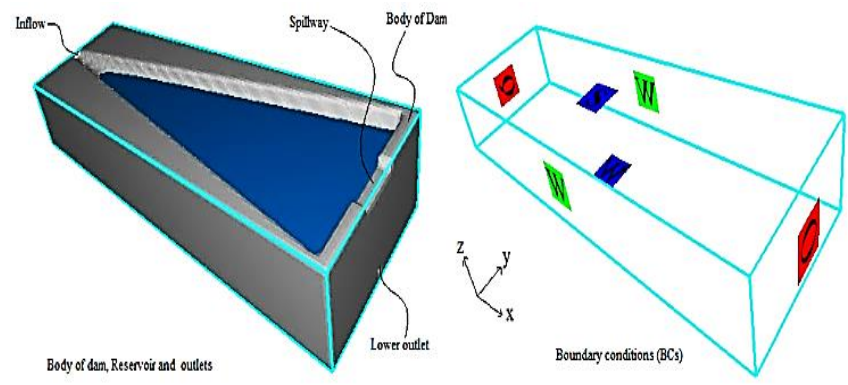

Figure 4. Boundary conditions of the models.

Eight separate simulations (scenarios) were performed under the scope of this study. A matrix of simulations performed during this study is represented in Table 2.

Table 2. Scenarios modeled using FLOW3D

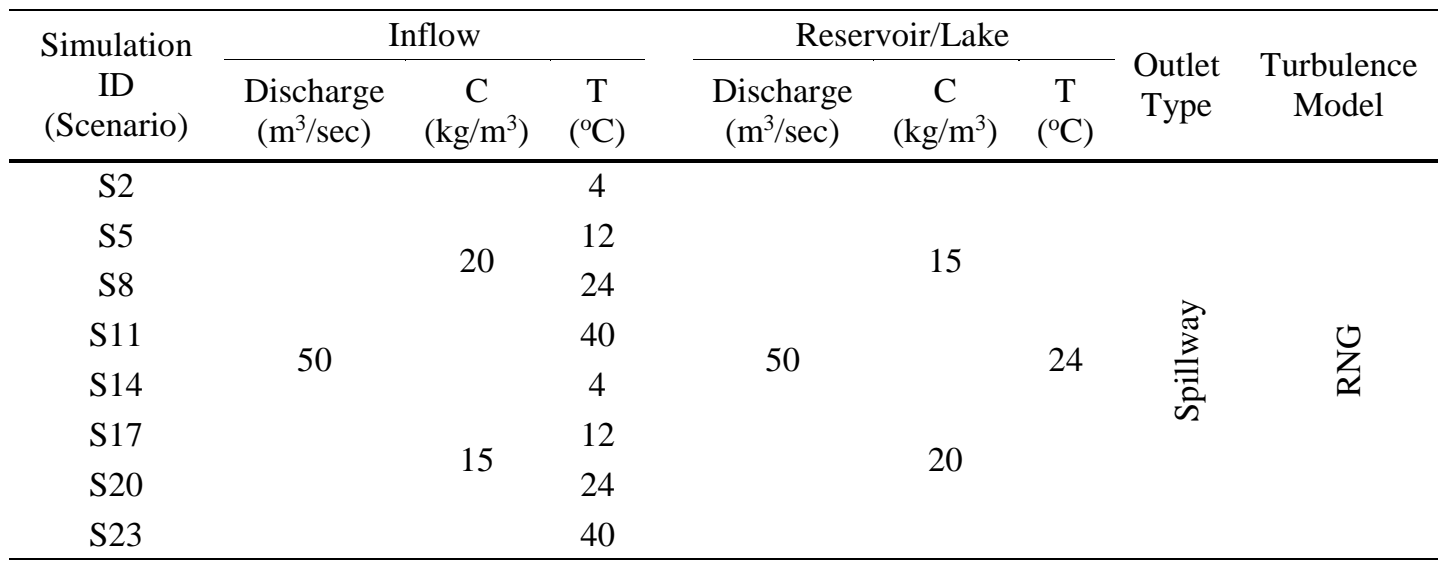

\section{RESULTS}

The results are compared in different simulation times included: $100 \mathrm{~s}, 150 \mathrm{~s}, 200 \mathrm{~s}, 250 \mathrm{~s}, 500 \mathrm{~s}, 750 \mathrm{~s}, 1000 \mathrm{~s}$, $1500 \mathrm{~s}, 2000 \mathrm{~s}, 2500 \mathrm{~s}$ and $3000 \mathrm{~s}$. These times indicate the time elapsed since the start of modeling. When time is equal to zero, it expresses the time that the inflow water (river) received to the reservoir and it is at the begining point of the reservoir. The results are compared at the middle of the width of the reservoir, where the $y$ is equal to 60 meters. The results are compared each other in two sections of the reservoir, which are shown in Figure 5. One of these sections was selected next to the dam body and the other one was in the middle of the reservoir. These sections are named as section 1 and section 2 withthe distance of
$250 \mathrm{~m}$ and $375 \mathrm{~m}$ from entrance of the reservoir, respectively. Colored temperature and suspended sediment concentration Contours of simulated scenarios are given in the Figure 6.

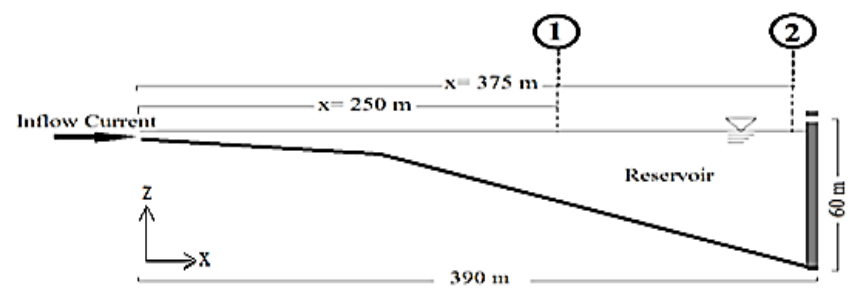

Figure 5. Situation of controlling sections. 


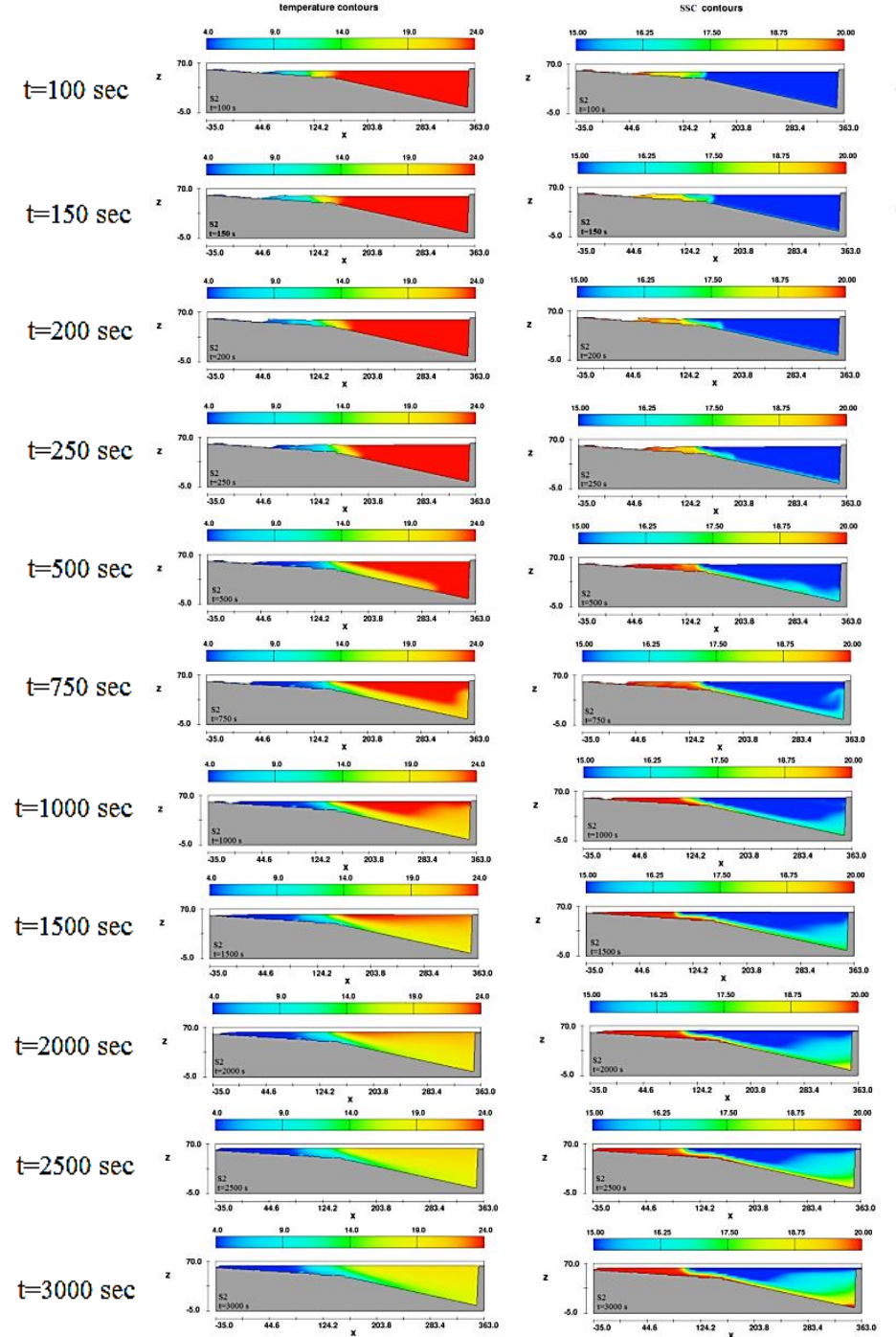

(a)
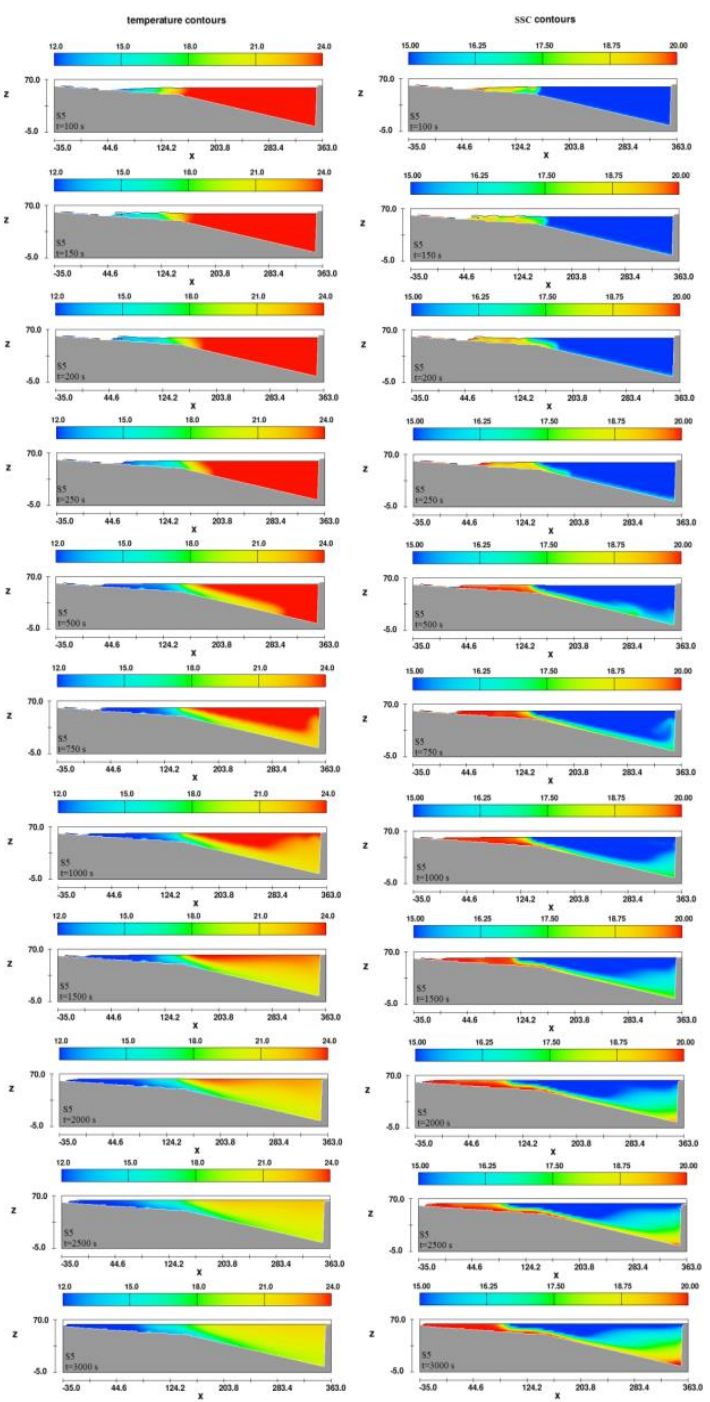

(b)

Figure 6. Temperature and SSC Contours of Simulation a) S2 and b) S5.

As the suspended sediment concentration of inflow current is higher than the reservoir's one, then the inflow water is denser than the reservoir one. As a result, it is expected that the under flow condition occurred (Figure 6). On the other hand, since the cold water is denser than warm and hot water, the inflow water is denser than the reservoir's one. Then it is expected that the inflow water sinks to the reservoir water and the thermal under flow condition occurs. Evaluating the results for S5 simulation shows that with changing in the temperature of the inflow current's water, the spread of temperature and suspended sediment concentration change. Effect of changings of temperature in inflow currents on distribution of suspended sediments particles are obvious in this simulation. Therefore, it affects the travelling time and distance of suspended particles in dam reservoirs. 


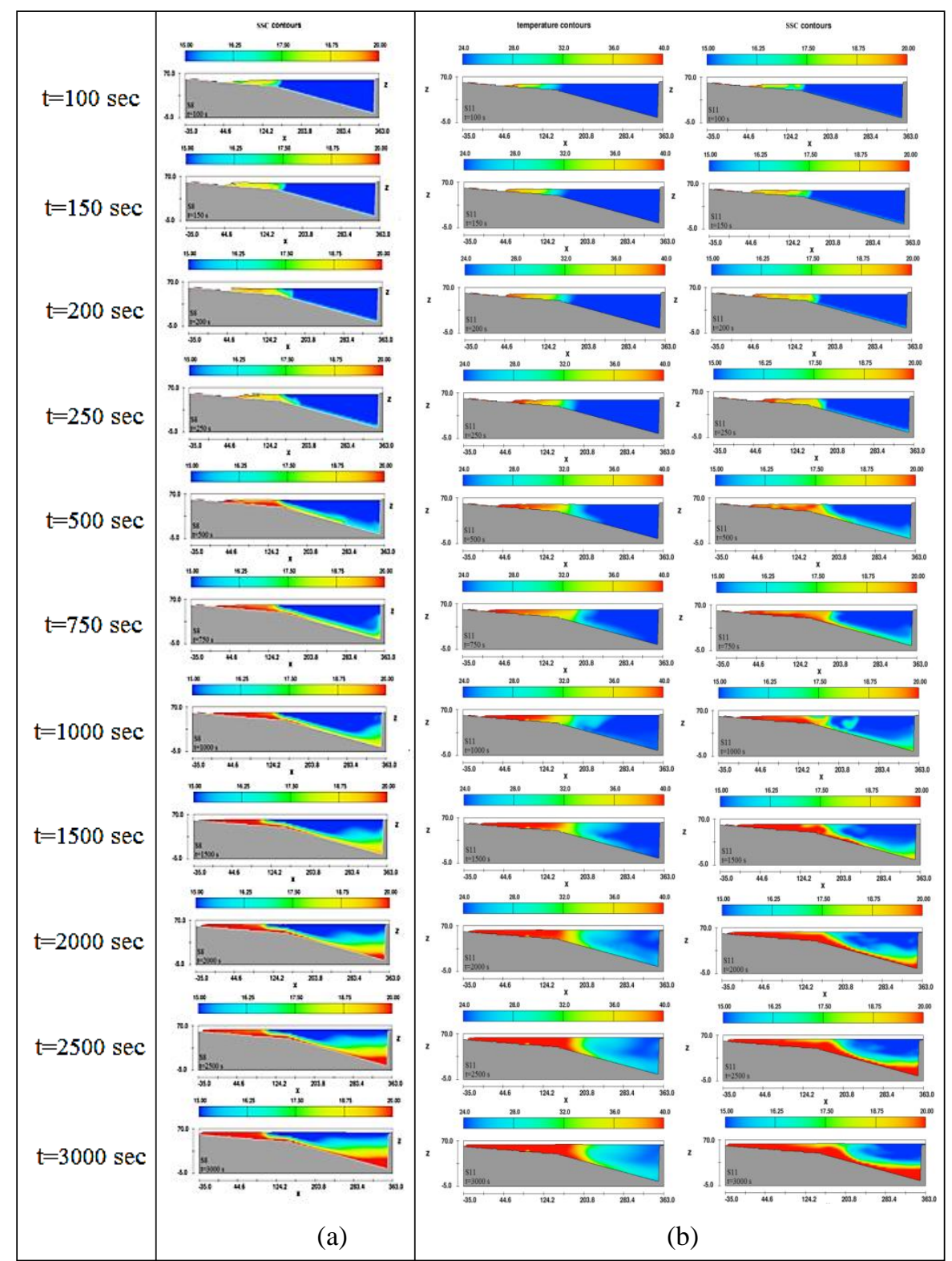

Figure 7. Temperature and SSC Contours of Simulations a) S8 and b) S11

In these simulations, velocity is increased at the upper layer of the reservoir. This increasing in velocity at the upper layer of reservoir, rises more near the dam body than the other places farther away from the dam body. It is because of the operation of spillway. As mentioned before, the temperature of inflow's water and reservoir are same and equal to $24{ }^{\circ} \mathrm{C}$ in simulation S8. It is clear, that this change is also affect the travelling time and distance of suspended sediment particles. As one of the main results it could concluded that temperature affects the plunge point situation of turbidity flows in reservoirs and lakes.

These results are presented as the comparative scatter plots for selected sections of the reservoir in Figure 7, and for different time scales included 1000, 2000 and 3000 seconds after running the simulation. 

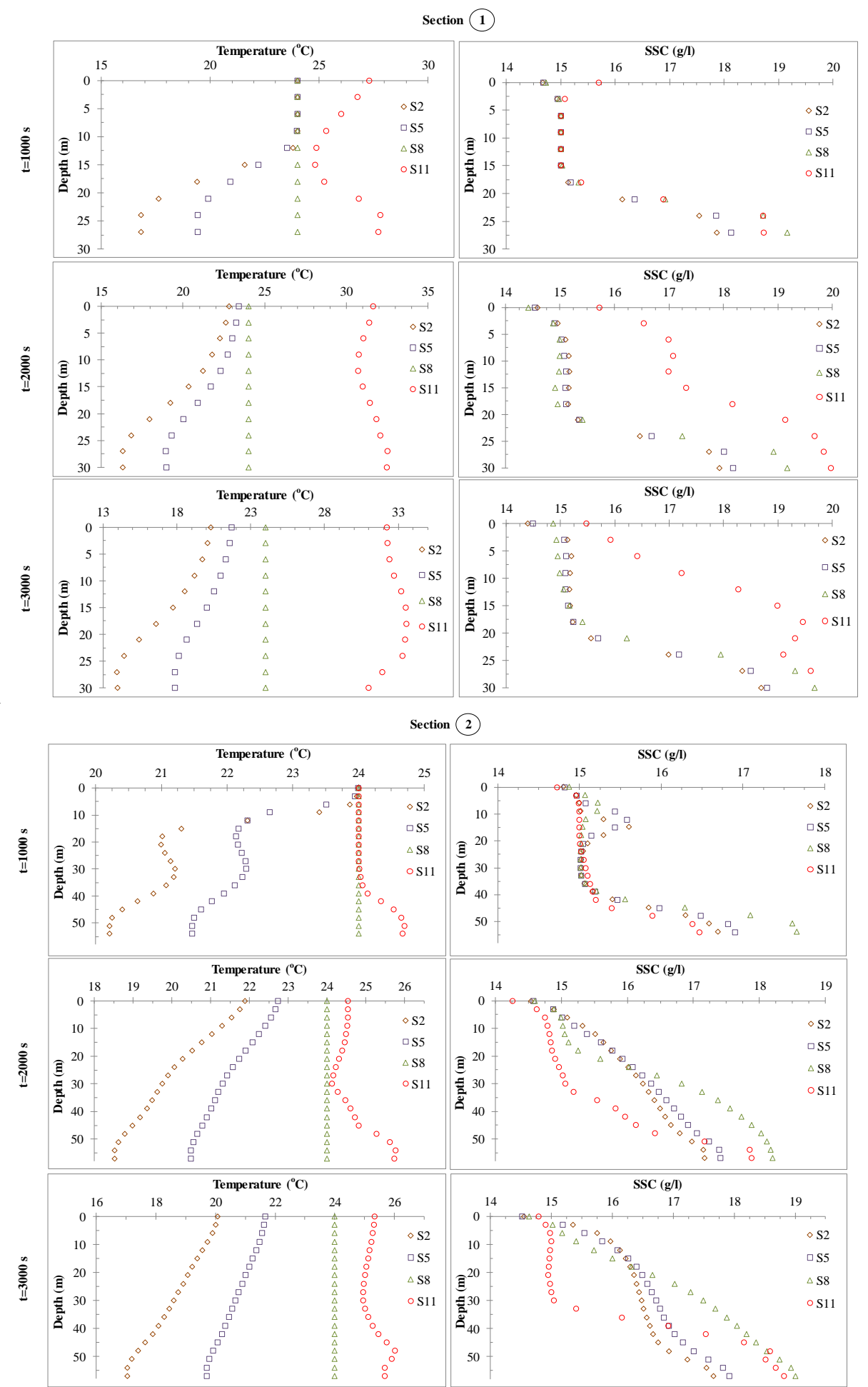

Figure 8. The comparative scatter plots for selected sections 1 and 2.

The spillway starts to operate after the time 700 seconds, approximately. After this time, the velocity at the upper layer of the reservoir and at the surface increases and direction of these velocity vectors are toward the dam body or downstream. So, the distribution of suspended sediment in this layer increase as the given Figure 8. It could conclude that the spillway increases the thickness of layers and helps to decreasing of the stratification.
In the other category of the simulations that were listed in scenario's table (Table 2), in which the concentration of inflow water is less that the concentration of the reservoir water, the inflow and reservoir concentrations were equal to 15 and $20 \mathrm{~kg} / \mathrm{m}^{3}$, respectively. So, based on the temperature of water in inflow current and reservoir, the water in reservoir is denser than the inflow water. It is expected that the over flow condition formed in these simulations. 


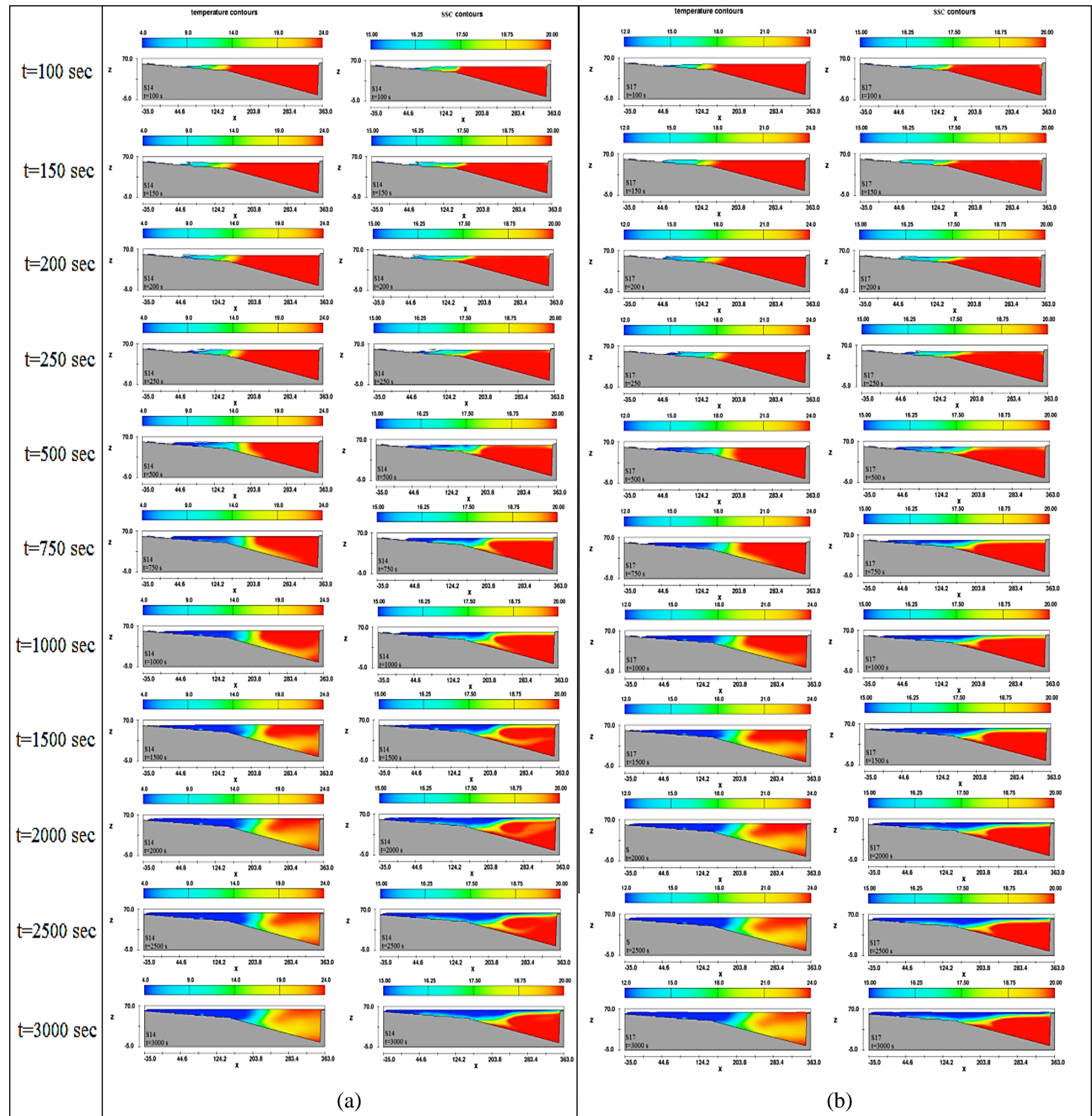

Figure 9. Temperature and SSC Contours of Simulation a) S14 and b) S17.

According to Figure 9, in simulation S17 temperature of the inflow current water is still less than the water temperature of the reservoir, as like as the simulation S14. It is a little warmer than the water temperature in simulation S14 and equal to $12{ }^{\circ} \mathrm{C}$. In this simulation, reservoir water temperature is as same as the $\mathrm{S} 14$, which is equal to $24^{\circ} \mathrm{C}$. Outlet type is still selected as spillway like other scenarios. About the suspended sediment concentration, the inflow current suspended sediment concentration is less than the reservoir's one. 


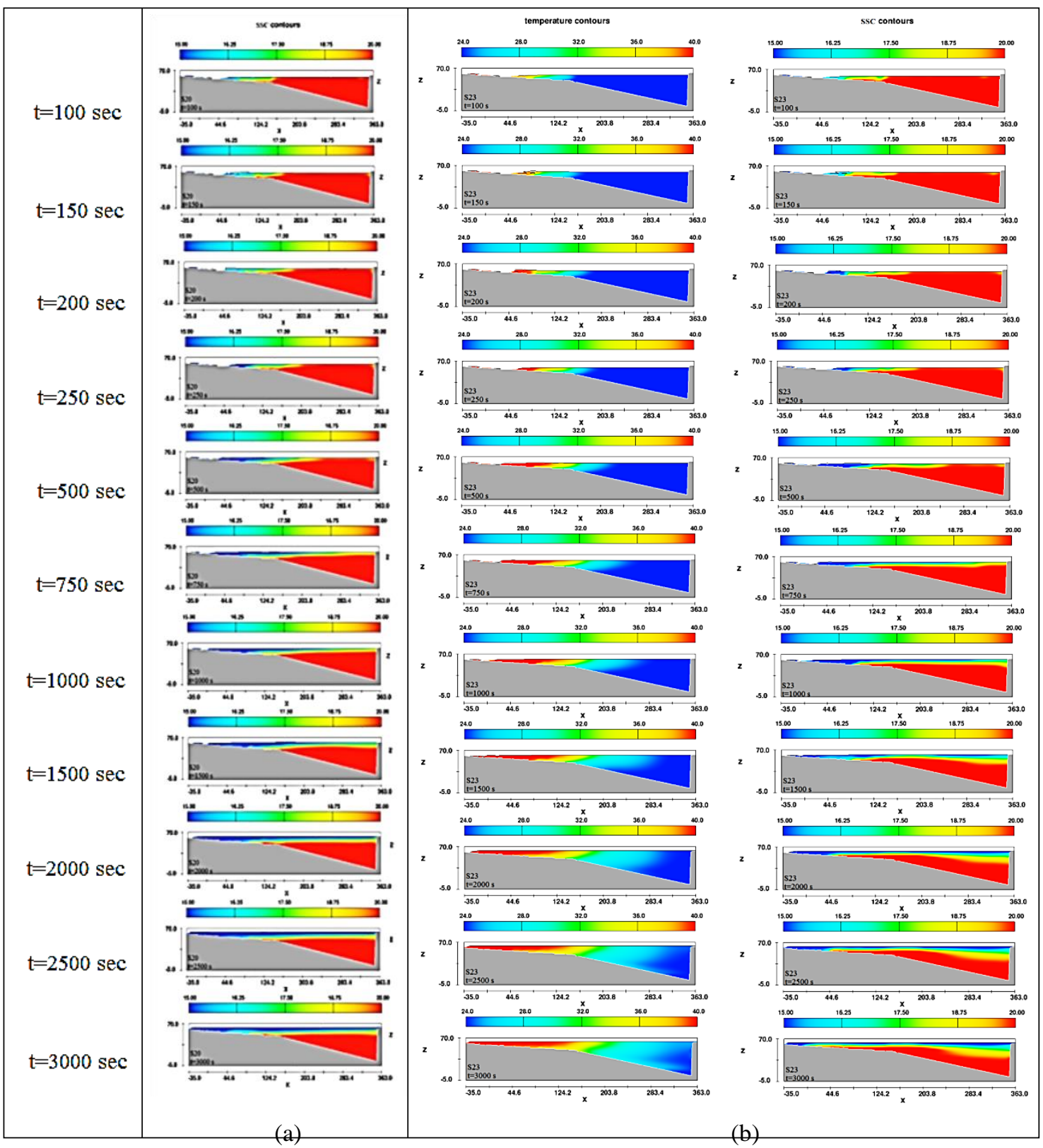

Figure 10. Temperature and SSC Contours of Simulation a) S20 and b) S23.

In simulation S20, the water temperature of the inflow current and reservoir are same and equal to $24{ }^{\circ} \mathrm{C}$. The existence of the spillway outlet affects the distribution pattern for temperature and suspended sediment. This kind of outlets increases the current velocity at the surface of the reservoir. In simulations S14, S17, S20 and S23, the over flow condition is occurred, obviously. These results are presented as the comparative scatter plots for selected sections of the reservoir and for different timescales included 1000, 2000 and 3000 seconds after running the simulation (Figure 10). 

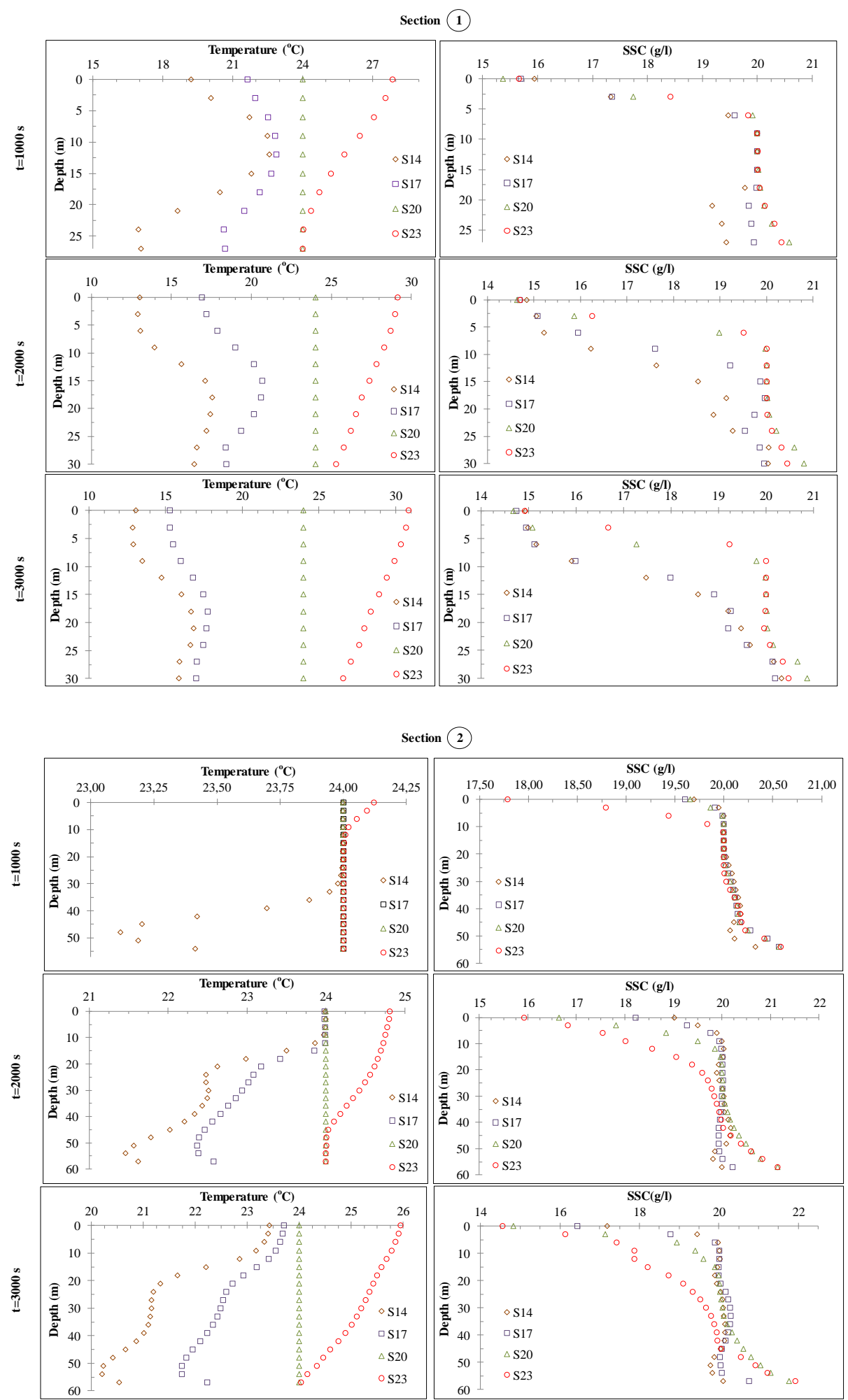

Figure 11. The comparative scatter plots for selected sections 1 and 2 .

From Figure 11, it could be demonstrated that in S2, S5, S8 and $\mathrm{S} 11$, the incoming flow into the reservoir is plunge at the beginning of the reservoir into the deeper layers and the turbidity current is formed. The obvious point that could be mentioned here is that the spillway has an important role in distribution of sediment and temperature during the turbidity current phenomenon. Another important point is that the effect of the differences between the inflow's water temperature and suspended sediment concentration and reservoir's water on distribution of the temperature and suspended sediment in the reservoir. 
Obtained results, which discussed above, were in a good agreement with the results obtained from studies done by other researchers in terms of water density differences, caused by differences in temperature and suspended sediment concentration. (eg. Zhong et al, 2020; Iwasaki and Parker, 2020; Chen et al., 2019; etc.).

\section{CONCLUSION}

Main aim of this study was to investigate and study on the distribution of the suspended sediment and temperature in lakes and reservoirs. The results of simulations show that the distribution of temperature and suspended sediment is under the effect of changes in some main parameters of inflow current and reservoir/lake. It is concluded that in the same conditions included the inflow water's suspended sediment concentration, reservoir's suspended sediment concentration, reservoir's water temperature and situation of outlet, with changing in inflow water temperature, there are some changes occurred in the situation of plunging point. Magnitude of discharge could affect the plunge point and the formation of the density/turbidity currents. But result of simulations in this study show that without applying any changes in discharge, there will occur some changes in plunging point situation, layers thicknesses, the distribution of suspended sediment and temperature. If density of inflow water is greater than the reservoir's one the density/turbidity currents will be formed obviously.

In simulations S2, S5, S8 and S11, when turbidity/density currents reached to the dam body, the current was moving upward with collision with body of dam and propagated and distributed into the upper layers of the reservoir near dam body. The existence of the spillway type outlet causes to increasing the velocity in layers near dam body and also at the surface of the reservoir. This rising in velocity leads to upward motion of suspended sediment in different layers close to dam body.

The rising in water temperature value leads to settling the suspended sediments faster. Therefore, the temperatures of inflow and reservoir water affect the depositing and settling of suspended sediments. Other words, water temperature could mainly affects the distribution of suspended sediment, the distance traveled by sediment particles and the thickness of formed stratified layers in lakes and reservoirs, directly.

Conflict of Interest: This study was produced from the PhD thesis entitled "Numerical Modeling of Stratified Dam Reservoirs and Lakes".

Financial Disclosure: The authors declared that this study has received no financial support.

\section{REFERENCES}

[1] M. Nazariha, E. Danayi, S. H. Hashemi, A. H. Izaddustdar, "Camparison of the Thermal Stratification of
Under Construction Bakhtiyari Dam at Reservoir and trasitional Area Using CE-QUAL-W2 Model". Enviromental Sciences and Technologies, VOL 13, No.3, 2008 (in Persian).

[2] D. E. Ford, M. C. Johnson, "An Assessment of Reservoir Density Currents and Inflow Processes", Technical Report, E-83-7, Prepared by Ford, Thornton, Nortonand Associates, Ltd, and the Environmental Laboratory, Waterways Experiment Station, for the U. S. Army Engineer Waterway Experiment Station, Vicksburg, Miss, (1983).

[3] M. R. Hipsey, J. D. Brookes, "Pathogen Management in Surface Waters: Practical Considerations for Reducing Public Health Risk", Current Topics in Public Health, Chapter 21, 2013

[4] J. D. Milliman, "Transfer of River-born Particular Material to the Ocean River Inputs to Ocean Systems", UNEP UNESCO, Switserland, P.5-12, (1981).

[5] L.C. van Rijn, "Sediment transport, part II: suspended load transport." Journal of hydraulic engineering 110.11: 1613-1641, (1984).

[6] G.P. Williams, "Sediment Concentration Versus Water Discharge During Single Hydrological Events in Rivers", Journal of Hydrology, No.111, P.89-106, 1989.

[7] S. Kostic, G. Parker, "Physical and Numerical Modeling of Deltaic Sedimentation in Lakes and Reservoirs", Proceedings, XXX International Association of Hydraulic Research Congress, (2003).

[8] N. L. Salant, M. A. Hassan, C. V. Alonso, "Suspended Sediment Dynamics at High and Low Storm", Hydrological Processes, 22. 1573-1587. 10.1002/hyp.6743, (2008).

[9] O. Algan, C. Gazioglu, Z. Yucel, N. Cagatay, B. Gonencgil, "Sediment and Freshwater Discharges of the Anatolian River into the Black Sea", IOC-BSRC Workshop Report, No.145,Paris,UNESCO,P.38-50, 2000.

[10] H. W. Fang, G. Q. Wang, "Three-dimensional Mathematical Model of Suspended Sediment Transport", Journal of Hydraulic Engineering, Vol. 126, No. 8, ASCE, 2000.

[11] USSD "Modeling Sediment Movement in Reservoirs", Report, Prepared by the United States Society of Dams, Committee on Hydraulics of Dams, Subcommittee on Reservoir Sedimentation, (2015).

[12] J. M. Dake, D. R. F. Harleman, "Thermal Stratification in Lakes: Analytical and Laboratory Studies", Water Resources Research, Vol.5, No.2, 1969.

[13] B.R. Hodges, J. Imberger, A.Saggio, K.B.Winters, "Modeling basin-scale internal waves in a stratified lake". Limnology and oceanography, 45(7), 1603-1620, (2000).

[14] P. Okely, J. Imberger, K. Shimizu, Particle dispersal due to interplay of motions in the surface layer of a small reservoir. Limnology and oceanography, 55(2), 589-603, (2010).

[15] m. Pilotti, G. Valerio, L. Gregorini, L. Milanesi, C.A. Hogg, Study of tributary inflows in Lake Iseo with a rotating physical model. J. Limnol, 73(1), 131-145, (2014).

[16] H.B. Fischer, E.G. List, R.C.Y Koh, J. Imberger, N.H. Brooks, "Mixing in inland and coastal waters". Academic Press, (1979). 
[17] R.H. Kennedy, K.W. Thornton, D.E. Ford, "Characterization of the reservoir ecosystem." Microbial Processes in Reservoirs. Developments in Hydrobiology, vol 27. Springer, Dordrecht. https://doi.org/10.1007/97894-009-5514-1_2, (1985).

[18] M. Modiri-Ghareveran, E. Jabbari, A. Etemad-Shahidi, Proceedings of the Institution of Civil Engineers - Water Management, 167:10, 601-611, 2014.

[19] N. H. Baharim, R. Ismail, M. H. Omar, "Effects of Thermal Stratification on the Concentration of Iron and Manganese in a Tropical Water Supply Reservoir", Sains Malaysiana, 40(8), P.821-825, 2011.

[20] M. Nazariha, E. Danayi, S. H. Hashemi, A. H. Izaddustdar, "Prediction of Thermal Stratification in Proposed Bakhtyari Reservoir with CE-QUAL-W2", World Environmental and Water Resources Congress 2009: Great Rivers, ASCE, 36. 1-8. 10.1061/41036(342)398, (2009).

[21] I. Nsiri, J. Tarhouni, M. Irie, "Modeling of Thermal Stratification and the Effect on Water Quality in Four Reservoirs in Tunisia", J Hydrogeol Hydrol Eng 5:1. doi:10.4172/2325-9647.1000132, (2016).

[22] R. Cossu, A. L. Forrest, H. A. Roop, G. B. Dunbar, M. J. Vandergoes, R. H. Levy, ..., S. G. Schladow, "Seasonal Variability in Turbidity Currents in Lake Ohau, New Zealand, and Their İnfluence on Sedimentation, Marine and
Freshwater Research", CSIRO Publishing, 2015. [23] J. Akiyama, H. G. Stefan, "Theory of Plunging Flow into a Reservoir", Internal Memo IM-97, St. Anthony Falls Hydraulic Laboratory, University of Minnesota, Minneapolis, Minn, 1981.

[24] G. J. Farrell, H. Stefan, "Mathematical Modeling of Plunging Reservoir Flows", Journal of Hydraulic Research, 26(5), P.525-537, 1986.

[25] FLOW 3D, "User Manual", Flow Science Inc., (2008).

[26] Yi Zhong, Lulu Qiao, Dehai Song, Yang Ding, Jishang $\mathrm{Xu}$, Wenjing Xue, Cheng Xue, Impact of cold water mass on suspended sediment transport in the South Yellow Sea, Marine Geology, Volume 428, 2020, 106244, ISSN 00253227, https://doi.org/10.1016/j.margeo.2020.106244.

[27] Toshiki Iwasaki, Gary Parker, "The role of saltwater and waves in continental shelf formation with seaward migrating clinoform". Proceedings of the National Academy of Sciences Jan 2020, 117 (3) 1266-1273; DOI: 10.1073/pnas. 1909572117.

[28] Chen, M., Pattiaratchi, C. B., Ghadouani, A., Hanson, C., "Seasonal and inter-annual variability of water column properties along the Rottnest continental shelf, south-west Australia". Ocean Sci.,Vol:15, 2, 333-348, (2019), DOI:10.5194/os-15-333-2019. 